\title{
独 Lancaster University MANAGEMENT SCHOOL
}

\author{
Lancaster University Management School \\ Working Paper \\ 2007/032
}

\section{The language of social entrepreneurs}

\author{
Caroline Parkinson and Carole Howorth \\ Institute for Entrepreneurship and Enterprise Development \\ Lancaster University Management School \\ Lancaster LA1 4YX \\ UK \\ (c) Caroline Parkinson and Carole Howorth \\ All rights reserved. Short sections of text, not to exceed \\ two paragraphs, may be quoted without explicit permission, \\ provided that full acknowledgement is given.
}


The Language of Social Entrepreneurs

\section{Caroline Parkinson and Carole Howorth}

Institute for Entrepreneurship \& Enterprise Development

Lancaster University Management School

Correspondence to:

Dr Carole Howorth, Institute for Entrepreneurship and Enterprise Development, Lancaster University Management School, Lancaster, LA1 4YX, UK. Telephone: +44 1524 594847. Email: c.howorth@lancaster.ac.uk

Acknowledgements: The authors would like to thank BNFL and J. and A. Baker for their financial support of this project. We would also like to thank all the social entrepreneurs who have given their time and shared their thoughts with us, the social enterprises who provided venues for interviews and the partners and agencies who provided advice and contacts. Opinions and interpretations (and the potential errors) expressed in this paper are, of course, the authors alone and do not necessarily coincide with those of the sponsors. 


\title{
The Language of Social Entrepreneurs
}

\begin{abstract}
This paper questions the application of the entrepreneurship discourse to social entrepreneurship in the UK and looks at how people 'doing' social enterprise appropriate or re-write the discourse to articulate their own realities. Drawing on phenomenological enquiry and discourse analysis, the study analyses the micro discourses of social entrepreneurs, as opposed to the meta rhetorics of (social) entrepreneurship. Analysis using both corpus linguistics software and Critical Discourse Analysis showed a preoccupation among interviewees with local issues, collective action, geographical community and local power struggles. Echoes of the enterprise discourse are evident but couched in linguistic devices that suggest a modified social construction of entrepreneurship, in which interviewees draw their legitimacy from a local or social morality. These findings are at odds ideologically with the discursive shifts of UK social enterprise policy over the last decade, in which a managerially defined rhetoric of enterprise is used to promote efficiency, business discipline and financial independence. The paper raises critical awareness of the tension in meanings appropriated to the enterprise discourse by social enterprise policy and practice and illustrates the value of discourse analysis for entrepreneurship and social entrepreneurship research.
\end{abstract}

Key Words: social entrepreneurship, social enterprise, discourse analysis, policy, community.

\section{I ntroduction}

Social entrepreneurship and social enterprises have been attracting widespread interest over the last decade in the UK, from a policy perspective particularly but also as a 'new' context for the study of entrepreneurship (Mair 2006). The encouragement of social enterprises is viewed as a central tenet of regional development strategies in the UK, 
particularly in areas of deprivation. People running social enterprises are held up as vital to the economy and a commitment to the development and growth of the social enterprise sector is being emphasised by policy makers at all levels. There has been a mushrooming of events, articles, books, journals, websites and specialist associations which reflect a growing interest in the social enterprise sector.

Within the rhetoric of social entrepreneurship, the language of business and entrepreneurship is held up as being the way forward for social enterprises. Pomerantz (2003: 26) expresses a widely-held view in writing “The key to social enterprise involves taking a business-like, innovative approach to the mission of delivering community services." The people who run social enterprises are often called 'social entrepreneurs' because they are expected to combine "entrepreneurial flair with a commitment to giving something back to the community" (Michael 2006).

However, the application of the entrepreneurship paradigm to the social sphere is questioned conceptually, practically and ideologically (Krashinsky 1998, Paton 2003, Pearce 2003, Dees 2004, Cho 2006). There are concerns that the repackaging of long standing community processes as a new form of entrepreneurship is neglecting some of the ideological and political principles at their roots (Pearce 2003). This could be symptomatic of the pervasion of business and managerial discourses into all domains of civil and public life (Paton 2003, Steyaert and Katz 2004), the dominance of managerial ideologies (J ohannisson 2002) and of political strategies connecting enterprise to socioeconomic needs. In any event, the shift from the community to the social enterprise 'era' (Pearce 2003) is loaded with philosophical and ideological tensions. The dominant economic philosophy at the heart of entrepreneurship is capitalism and free market economics (Jennings et al. 2005) and the market analogy is implicit in social enterprise (Cho 2006). Paton (2003) argues that social entrepreneurs and enterprises operate in a different world of meaning. The unquestioning use of managerial discourses could undermine the very attributes of social enterprises that are their strength (Krashinsky, in 
Paton 2003) and neglect the political and dialogical practices at the centre of social entrepreneurship (Cho 2006).

Previous studies in the field of social entrepreneurship have revealed conceptualisations of success and performance among people managing social enterprises that are radically different to those gleaned from a reading of the social entrepreneurship rhetoric (Parkinson 2005); others have highlighted the tension between an emphasis on the individual in entrepreneurship and the collective basis of social enterprises (Cho 2006, Spear 2006); and discussions about the problems of valuing social enterprises continue to highlight the divide between a business and policy emphasis on financial or numerical measures and the social enterprises' focus on social or local outcomes (Amin et al. 2002, Haugh 2006). This indicates the potential for discursive tension between policy makers, funders and support agencies on the one hand and the people 'doing' social enterprise on the other. The implications could include lack of understanding, conflict, misallocation of resources and loss to the sector. Without an understanding of why people engage in social entrepreneurship, and how they feel about social change (Perrini and Vurro 2006), policies aimed at supporting the sector may be flawed.

As might be expected in the early development of a field, much of the existing research is atheoretical and there is a lack of high level research that develops critical and conceptual analysis. The majority of existing studies tend to provide descriptive statistics and illustrative case studies. While this has been helpful in profiling the sector, commentators are calling for new and interdisciplinary approaches that reflect the complexity and ambiguity that characterise activity in the social or community context (Krashinsky 1998, Dees 2004, Paton 2003, Pearce 2003, Mair and Marti 2006, Austin 2006, Perrini and Vurro 2006).

This is not new. Definitional and conceptual difficulties have dogged entrepreneurship research (Gartner 1988), leading researchers to urge greater paradigmatic freedom and 
interdisciplinary exploration more appropriate to the complexity of entrepreneurship (Chell and Allman 2001, Grant and Perren 2002, Steyaert and Katz 2004, Howorth et al. 2005). The perpetual reconceptualisation and redefinition, now well stated, has frustrated researchers in the field (for example, Ogbor 2000; see also Jones and Spicer 2005 for an interesting discussion) who claim that research has failed to pin down 'the entrepreneur' or entrepreneurship. The only consensus seems to be around what entrepreneurship is not: a static entity that is the preserve of elite individuals with special personality traits or characteristics. Instead, a multi-faceted, dynamic understanding of entrepreneurship is emerging that presents challenges to research, breaks with functionalist positivism and calls for constant review of epistemological and ontological presumptions (Shane and Venkataraman 2000, Busenitz et al. 2003, Fletcher 2006).

In the case of social entrepreneurship, the field is caught up in ever deeper conceptual problems inherent in both the concept of social itself and the tautology of 'social' and 'entrepreneurship' (Cho 2006). Despite the interdisciplinary nature of the subject area, much of the current work has come out of business and management disciplines (Marti 2006), and has been preoccupied with understanding social entrepreneurship in terms of the 'mainstream' (see for example Mair and Marti 2006, Mair 2006,), instead of as a complex social movement in its own right (Alvord et al. 2004). Paradoxically, the hunt is still on in this field for a 'unifying paradigm' (Shane and Venkataraman 2000, Mair 2006).

At the same time, a number of papers over the years have sought to link entrepreneurship with different aspects of society or contexts. The reciprocal benefits from the interaction between firms and their local environments has been an important area of study (Tolbert et al. 1998, Kilkenny et al. 1999, Laukkanen 2000, Johannisson et al. 2002). A major body of literature has looked at the problematic connections between entrepreneurship and deprivation (Lloyd and Mason 1984, Haywood and Nolan 2003, 
Nicholls 2004, Southern 2005), particularly in regeneration and economic development policy terms. The informal economy (Portes 1994, Evans et al. 2004, Williams 2005) and ethnic minority enterprise (Ram and Smallbone 2003, Deakins et al. 2007) are among other contexts, along with social entrepreneurship and enterprise. Enterprise policy aimed at combating social exclusion is critically reviewed (Blackburn and Ram 2006), pointing to the danger of overstating the small business contribution to social exclusion, a complex multidimensional phenomenon. With each of these applications, conceptual clarity is both necessary and challenging.

Our starting point is to consider the discourse of social entrepreneurship. Discourses are constitutive of meaning and power (Foucault 1972, Fairclough 1989, 1992, 1995, Wodak 2003) and can influence people's involvement in the processes aimed at transforming them or their communities (see for example studies by Collins 1999, Hastings 2000). This paper looks at the concepts and language that are central to people labelled as social entrepreneurs, in order to understand how, indeed if, the entrepreneurship discourse is modelled and enacted by them. The language used by social entrepreneurs is studied using a corpus linguistics tool that throws into relief key words and concepts by comparing it to a corpus of spoken text by the general UK population and, then, to a comparable sample of interview transcripts from business entrepreneurs. Samples of the interviews are then studied in depth, allowing us to examine how far the linguistic shift towards social entrepreneurship is embraced by the subjects of the discourse. Our findings highlight areas of potential tension and misinterpretation between social entrepreneurs, advisers, policy makers and others - including researchers.

The following section provides a context for this study from the entrepreneurship and social entrepreneurship literature. This is followed by an explanation of the methods and definitions employed. The analysis looks at the language employed by social entrepreneurs when asked to talk about their work - and contrasted against business entrepreneurs on the same topic, not as a means of comparing directly but in order to 
highlight key themes. Detailed analysis of samples of discourse develops themes to provide more explanation and understanding in depth. In the discussion and conclusion sections that follow we highlight the implications of our findings for all those involved in researching, promoting or delivering the social enterprise agenda.

\section{Context}

\subsection{The social in entrepreneurship}

The field of entrepreneurship research, having reassessed the reliance on a functionalist, economic perspective, is now characterised by approaches that deal differently with the subjectivity of the topic. Covin and Slevin (1991), in their firm level analysis, draw together much of the earlier entrepreneurship research into three factors, namely proactivity, risk management and innovativeness. Shane (2003) suggests that entrepreneurship occurs at the 'nexus of individual and opportunity,' building on the theme of opportunity alertness (Kirzner 1973). Others highlight the process of entrepreneurship (Gartner 1988) and they emphasise the start-up, organisation and development of a venture as encompassing entrepreneurship. More recently, studies have focused on the social, cultural, historical and structural factors (see Jones and Spicer 2005: 235, for a review of works focusing on structural factors of entrepreneurship) and an emerging approach draws on economic sociology and the sociology of enterprise (Zafirovski 1999).

Fletcher (2006) makes the case for using social constructionist ideas to look at entrepreneurial processes as communally and relationally constituted, rather than deriving from private sense making, dislocated from its social and human context. Increasingly, entrepreneurial processes are perceived as socially embedded and constructed, complex products of their milieu. Interest is in the interplay between people and their situation, and social variables including class, ethnicity and morals 
(Zafirovski 1999, Hodson and Kaufman 1982), institutions, language and ideologies (Fletcher 2006) and networks and rules (Anderson and Jack 2002).

In the departure from mainstream economic theory, where entrepreneurship is conceived as a rational phenomenon, entrepreneurship is seen instead as a process taking place in various spaces and dimensions. Entrepreneurial processes have meaning that is specific to a particular time and place (Hjorth and Johannisson 2003, Fletcher 2006). Steyaert and Katz (2004) talk of the various dimensions in which entrepreneurship is conceived and played out. Entrepreneurship is described as embedded, in that business activity is a reflection of complex socio-economic phenomena (Johannisson et al. 2002). Here, networking is socio-centric and happens across several layers of embeddedness; and locality is a collectively constructed environment in which firms co-construct the local development conditions (J ohannisson et al. 2002:299). Finally, entrepreneurial processes are also seen happening in inbetween spaces. Anderson talks of the 'liminality' of the entrepreneurial condition, a transformative state at the limits of existing structures, in which the process of becoming something new is between past and future. For Jones and Spicer (2005) too, entrepreneurship inhabits the gap between the subject (the entrepreneur) and what they seek to attain.

While predominantly conceived as a process, entrepreneurship is nonetheless dependent on people to enact it (Anderson and Jack 2002, Johannisson et al. 2002). It is enacted, according to implicit sets of rules that shape and structure practices (Zafirovski 1999, Anderson and Jack 2002), linked to the past but alterable by entrepreneurial enactment. Anderson (2005) suggests, further, that entrepreneurship is not only enacted but performed. In his dramaturgical approach to entrepreneurial enactment, role playing and impression management are key to the entrepreneur's self-promotion. Rather than operating as rational actors, entrepreneurs are affected by irrationalities and anomalies (Johannisson 2002) and constrained by cultural factors, such as those above, that exert 
a constant force on economic life (Zafirovski 1999). There is a growing sense that entrepreneurship is inevitably experienced and reproduced in mundane, daily lives (Cohen and Musson 2000, Steyaert and Katz 2004).

This discussion suggests that entrepreneurship is essentially an indefinable concept that is idiosyncratic, perpetually morphing and intrinsically unstable (Anderson 2005, Jones and Spicer 2005). Looking at the micro construction of meaning on the ground as well as the macro perspective is important. The following section looks at the linguistic turn in entrepreneurship studies (Hjorth and Steyaert 2004), specifically discourse analysis, as one approach in social constructionist thinking.

\subsection{Discourse and entrepreneurship}

Studies in many areas of social policy and social science have used discourse analysis to explore relational, ideological and political struggles (Atkinson 1999, Collins 1999, Hastings 1999, 2000, Stenson and Watt 1999, Jacobs 2004). Discourse and narrative methods have been used to a limited extent in entrepreneurship research (for example, Ahl 2004, Hjorth and Steyaert 2004, Lindh de Montoya 2004).

There has been particular interest in the enterprise culture, with its various meta rhetorics and discourses, since Thatcherism in the UK in the 1980s. The enterprise discourse is often portrayed as hegemonic, assuming a Foucauldian stance that language is a reflection of power relations, struggles and dynamics (Foucault 1972, see also J ones and Spicer 2005 for a discussion of Foucault in du Gay's analysis of the enterprise culture du Gay 1991, 2004). For Foucault, discourses are 'practices that systematically form the objects of which they speak' (Foucault 1969, quoted in Parker 1999), and determine how power and knowledge are produced. Sets of discursive practices delimit the boundaries of debate (Foucault, 1972) and become self policing. Discourse analysts 
who have built on Foucault 'fracture texts into different discrete discourses which then hold positions for speakers and reproduce relations of power' (Parker 1999:3).

The apparent hegemony of the enterprise discourse is perpetuated in the popular media, where entrepreneurs are held up as heroes with special qualities or as quick-witted wheeler-dealers. In his work on the entrepreneurial metaphor, Anderson (2005) points to the persistent power of the heroic entrepreneurial metaphor. Nicholson and Anderson (2005) propose that the myth embodied in cultural beliefs, popular literature and journalism becomes self-perpetuating; mystery is created around the myth of the entrepreneur and perpetually reinforced. The mystery shrouding the myth grows, the myth becomes shorthand and eventually 'the uncorrected "collective memory"'. (Nicholson and Anderson 2005: 166). The discourse of the enterprise culture, independent of the theoretical advances outlined above and the rise in interest in collective processes, can be seen as re-asserting individualism (Nicholson and Anderson 2005).

Dictionary definitions validate this common understanding of an entrepreneur, referring to someone who undertakes an enterprise or business with the chance of profit or loss (Concise Oxford Dictionary, $9^{\text {th }}$ edition). This definition encompasses proactivity, risk and the entrepreneurial process but does not include innovation, although this would almost certainly be central to the current popular image of an entrepreneur. The definition also introduces the concept of profit and separates business from enterprise.

Recent literature has taken up a challenge to the hegemony of the enterprise discourse, however. The Foucauldian perspective and its antecedents are criticised for assuming that the individual is slave to ideologies or discourses and is powerless to resist the 'call' (Cohen and Musson 2000, Jones and Spicer 2005). That view of the individual is seen as too deterministic, leaving no room for individuals to resist and find their own alternative discourses. The focus instead is on how people appropriate or re-write the discourse to 
make sense of their specific realities; a reflection of the interest in entrepreneurship as a socially embedded and constructed phenomenon rather than an economic reality. Interest is in the relationship between meta discourses and their use at the micro level.

Various studies show people reproducing idealised views of entrepreneurs and being entrepreneurial, while simultaneously challenging and re-writing the enterprise discourse (Fletcher 2006, Cohen and Musson 2000). Cohen and Musson (2000), in their study of GPs and women entering self-employment, look at the talk of individuals to see how the enterprise discourse is used and internalised, drawing on Fairclough's theories of a dialectical relationship between discourse and social structure (Fairclough 1992). Contrary to the hegemonic view, this study presents people as able to discriminate between discourses and appropriate them to their circumstances. In the struggle between competing discourses, elements of the business or enterprise discourse are appropriated and others rejected. People find relevance in the enterprise discourse through their own reading of it (Cohen and Musson 2000). Consequently, meaning cannot be solely constructed by those in positions of power to exclude or include certain groups, since this is also alterable by the subjects of the discourse.

Similarly, we draw on Fairclough (1989, 1992, 1995) and Wodak (2003), who suggest that discourse is more than reflective of social power situations, in that language use influences, as much as it is influenced by, social practice. Discourse must therefore be studied in reference to the social and political context (Fairclough and Wodak 1997). Critical discourse analysis includes situations, objects of knowledge and the social identities of and relationships between people and groups of people (Weiss and Wodak 2003). Language is constitutive of meaning, the 'prism through which we conceptualise the world' (Jacobs 2004:819) and is seen as a social practice shaping, and shaped, by social relations and structures. If this is the case, it is important to consider the effects of the entrepreneurship discourse on the subjects, particularly in an already highly contested realm such as the social or community. 


\subsection{The entrepreneurship discourse in 'social' entrepreneurship}

As pointed out by a reviewer of this paper, the contested and fluid nature of entrepreneurship makes it fundamentally tricky to try and compare against a moving semantic target. In many ways, this was our starting point: the unquestioned application of the entrepreneurship paradigm to social activity that until recently was located within other, equally dominant discourses of the modern western world.

Social entrepreneurship, broadly defined for this study as the use of entrepreneurial processes for social purpose, is itself the site of ideological and power struggles at root. Many clearly locate social enterprise within community or economic development, where it has a political agenda of alternative democratic structures and processes. For example, Wallace (1999) traces the development of the current social purpose enterprise paradigm in the US through various movements, from community activism and leadership, civic emancipation, economic empowerment through self-sufficiency, political mobilisation for neighbourhood improvement and self reliance. Pearce (2003) traces the history of the movement in the UK back to the 1970s J ob Creation Programme, when the focus was on community development, and the cooperative movement. Haughton (1998) situates the UK movement within sustainable regeneration, itself a response to the failure of top down urban policy approaches throughout the 1980s. Social and community entrepreneurship in the UK emerged out of structures aimed at anchoring the benefits of the local economy within communities.

The discourse of social entrepreneurship is arguably the result of a wholesale shift over the last decade, particularly in the UK, from the community to the social era (Pearce 2003, Drucker 1994). It was not until the end of the 1990s that the discourse around social enterprises as businesses emerged in the UK. Since then, the topic has seen a 
radical and rapid discursive shift through various agendas, including some mentioned above, to the social economy and social entrepreneurship.

A reading of principal writings and documents relating to social entrepreneurship in the last five years reveals heroic claims that social entrepreneurship reaches the parts of society other policy initiatives do not reach, that social entrepreneurs are unsung heroes and alchemists with magical qualities who can build things from nothing (Dees 2004). It is assumed that social enterprises will take on the existing business model, which excludes the potential to develop new models. For example, 'Social enterprises must see themselves as businesses, seek to become more professional and continuously raise their standards of performance and their ambitions' (DTI 2002). And social enterprises are encouraged to be part of the mainstream economy: 'social enterprise should "become part of the solution to reviving and strengthening local economies" but "should not be seen as a side show to the real economy" (NWDA 2003).

This discursive shift has entailed, Pearce argues, a shift in language from political engagement to problem fixing, collective action to individual entrepreneurs, and from democratic structures to a focus on social purpose (Pearce 2003). The charge is that in the rise of the social enterprise agenda, community has been sidelined discursively and complex values and meanings behind the social ignored. This has happened in two main ways.

Firstly, as has been the case with entrepreneurship, stronger emphasis is placed on individuals, rather than the collective (Holmquist 2003, Cho 2006), to bring about social change. This has resulted in a sense of elitism, reflected in current preoccupations with, for example, how to spot potential and back the winners. If the 'everydayness' or 'prosaics' of entrepreneurship (Steyaert 2004) are important for understanding its ubiquitous potential, rather than as the privilege of the few, then 'empowering the many' in the community context is important (Pearce 2003:69). Instead, the monological 
aspect of the 'entrepreneurial turn' (Cho 2006) that promotes individual agency is reproducing a focus in social entrepreneurship research on people who are 'special in perceiving and enacting opportunties others don't see' (Robinson 2006). Social entrepreneurs in many studies are understood either in comparison with, or in contrast to, their private sector counterparts (cf Shaw et al. 2001, Perrini and Vurro 2006). This is now critiqued by some (Haugh 2006) and a new focus is emerging on social entrepreneurial processes and opportunity identification, where agency is conceivable as collective.

Secondly, a tension around using entrepreneurial involvement to fill social gaps is noted (Perrini and Vurro 2006). Throughout the discourse, social entrepreneurship is overtly posited as the panacea to failure in market and state mechanisms. In this, it is explicitly manoeuvred into a technocratic function of serving underserved parts of society, where people engaged in social entrepreneurship take on a palliative role (Cho 2006). This managerially defined position, marked by a general emphasis on performance, impact, efficiency and sustainability, detracts from a more political-ideological function. It simultaneously disarms the 'third sector' of radical approaches to civil society and maintains the distance between state and parts of society served by social entrepreneurship (Cho 2006).

Entrepreneurship as applied to social entrepreneurship reinforces the old. While there is still no consensus on the definition of an entrepreneur or entrepreneurship, much is being carried over wholesale to the study of social entrepreneurship, as a new context. For example, Covin and Slevin's framework of proactivity, risk management and innovativeness at the level of the firm (Covin and Slevin 1991), has recently been employed in social entrepreneurship research (Weerawardena and Sullivan Mort 2005), the suggestion being that the existence of these three factors is evidence of acting entrepreneurially. 
As with 'mainstream' entrepreneurship before it, the promotional rhetoric (Dees 2004) has led to a research focus characterised by functionalist and positivist approaches. Paradoxically, given its collective and political-ideological roots, the study of social entrepreneurship might be more prone now to individualistic and economic presumptions than 'mainstream' entrepreneurship, where such perspectives have been long since questioned.

In this paper, we acknowledge the dynamic complexity of the entrepreneurship paradigm but take an interpretive approach rather than start from problematic definitions. As others, we feel the need to 'resist premature definitional closure' (Marti 2006: 17). As Cohen and Musson (2000), we are chiefly interested in the interplay between the meta rhetorics of enterprise and on-the-ground constructions, in other words how far the entrepreneurship discourse is seen as meaningful, or otherwise, by individuals engaged in social entrepreneurship. Our subjects, identified by others as social entrepreneurs, are individuals who are expected to assimilate the enterprise discourse, according to the contemporary agency rhetoric.

Considering the influence of the entrepreneurial discourse, discussed earlier, different responses to the rhetoric could be expected. Those interviewees whose frame of reference is a populist view of entrepreneurship, for example, may be expected to talk in terms of individual, heroic traits and characteristics. Social entrepreneurs who embrace entrepreneurial language and terms, on the other hand, could be expected to talk about being proactive, managing risks, innovation, opportunities, and the start-up and development process. 'Social entrepreneurs' who feel most ill at ease with business language might be those with a higher commitment to social aims. Alternatively, social entrepreneurs may adopt a frame of reference more closely aligned with community action than business or entrepreneurship. This would be exhibited in language around community and local issues and could be in addition or as an alternative to entrepreneurship. 
It is probable that our 'social entrepreneurs' have never delved into academic research and their understandings of what entrepreneurship entails may differ. Throughout, it is important to be aware that the philosophy underpinning the approach taken by researchers and policy makers can affect what is investigated and discovered. This in turn influences the direction and development of our theories and understanding. The following section discusses how our approach has attempted to capture understandings.

\section{Methods}

Data was collected through tape-recorded phenomenological interviews with 20 social entrepreneurs, lasting 45 to 60 minutes. Phenomenology, in this case specifically the phenomenological interview, is an interpretative approach to qualitative research, used increasingly in entrepreneurship (Thompson et al. 1989, Cope and Watts 2000, Cave, Eccles and Rundle 2001). Starting from the perspective of lived experience, phenomenology emphasises discovery and description, rather than proving or justifying theories (see Cope 2003 for a discussion). The methodology is inductive in that the researcher's theoretical stance is shelved, as far as possible, and propositions are allowed to emerge out of the research. It is this grounded, interpretive aspect of phenomenology and its potential for gaining insight into others' experience and point of view that makes it suitable for this research.

Five local agencies (funders, intermediaries and support agencies) were asked to identify and nominate social entrepreneurs. Basic characteristics of the social entrepreneurs are presented in Table 1. In order to maintain confidentiality, individuals are not identified.

Interviewees were informed in advance of the overall topic of the research. All interviews started with the request, 'Tell me what you do' and then allowed to take their 
own direction. Open questions e.g. 'how...', 'why...' were used as a way of facilitating reflection.

Interview data were analysed in two stages. Firstly, Wmatrix was used to present a snapshot of the linguistic content. The Wmatrix software 'allows the macroscopic analysis (the study of the characteristics of whole texts or varieties of language) to inform the microscopic level (focusing on the use of a particular linguistic feature) as to which linguistic features should be investigated further' (Rayson 2002) and is based on corpus linguistics (McEnery and Wilson 2001). This exercise identified significant differences in lexical and semantic frequencies in the combined social entrepreneurs' texts, compared to two other corpora of spoken texts: British National Corpus of Spoken English (BNC) and the Corpus of Entrepreneurship and Small Business (CESB) developed at Lancaster University. The corpus of general entrepreneurs (CESB) were all private sector entrepreneurs, selected because of similar sample size, interview method (phenomenological) and research topic (interviewees also asked to talk about success and failure). Words and concepts are analysed in terms of degree of difference (log likelihood) against the norms of each corpus. Frequency lists were produced for each corpus and the log likelihood of words and concepts, relative to the larger normative corpus, were calculated to test whether frequently occurring words or concepts appeared significantly more (or less) frequently in the social entrepreneurs' texts (for a detailed explanation of this method see Rayson, 2002).

Secondly, five interviews were selected and in-depth critical discourse analysis was undertaken on sections of the text from their transcripts. Critical Discourse Analysis is an intensive and detailed process that could only be applied to samples of the interviews for practical reasons. The five interviews, were chosen to reflect differences that might theoretically be expected to influence the language used. The five interviews included differences in terms of gender (three female, two male), local origin (three local, two incomers), nature of their social enterprise activity (spread across the categories in Table 
1) and apparently high affinity or resistance to the enterprise discourse from an initial reading. Sections for analysis were selected either because of their relevance to the research question or, as Fairclough (1992) suggests, because they contain moments of apparent crisis or cruces, such as hesitation, redefinition, repetition, contestation or deliberation.

This paper uses a framework drawn from Fairclough (1992). Analysis is critical in its connectedness to social issues (Van Dijk 1997), with analysts making explicit their social and political position: 'Analysis, description and theory play a role especially in as far as they allow better understanding and critique of social problems. Their ultimate goal is not only scientific but also social and political, namely change.' (Van Dijk 1997:22-3).

Critical discourse analysis of the text samples comprised a three stage process:

1 First the macro processes of text production, distribution and consumption were examined. This involved looking broadly at the context within which statements were made, how they connect to other debates and how the interviewees generally framed their spoken texts. The purpose was to highlight how social entrepreneurship talk is framed by, and takes its meaning from, different agendas.

2 More detailed text analysis then looked at the micro processes of discourse that shaped the text (Fairclough 1992:86), including text cohesion, ethos, grammar, theme, modality and word meaning. How interviewees choose to structure what they say can reveal innovation in wordings and understandings of agency.

3 Finally the analysis examined social practice, which is concerned with how the interviewees reproduce or transform social structures in their spoken text and the intended and unintended effect of the texts on wider power relations and ideologies.

The focus here is on talk as 'it is in this mode of language where the dialogical nature of linguistic activity is most obvious' Hastings (2000:134). So although an interview, as with a politician's speech, may not appear dialogical (see Fairclough 1992, Hastings 2000, also Anderson 2005 in relation to the stage and audience), the listener is still part 
of the production of meaning through interpretation. The following section considers first of all the findings of the analysis of linguistic content before discussing the critical discourse analysis.

\section{Results}

\subsection{Key words and concepts}

The first stage of analysis is to compare the actual words and language used by social entrepreneurs with that used by general entrepreneurs and with general spoken English and the results are presented in Table 2. Column 1 of Table 2 contains the results of social entrepreneurs compared to general spoken English (British National Corpus of Spoken English). Column 2 presents the results of private sector entrepreneurs (Corpus of Entrepreneurship and Small Business) compared to general spoken English (BNCSE). Column 3 compares spoken texts of social and private sector entrepreneurs. The list of words and key concepts are presented in order of greatest difference. In reading the table, a positive sign in columns 1 and 3 indicates that the word or concept is used significantly more by social entrepreneurs and vice versa for a negative sign. In column 2 a positive sign represents over use by private sector entrepreneurs and vice versa for a negative sign. All the differences were statistically significant at $1 \%$ level of significance.

The words and concepts identified in the first column are of greater interest when considered alongside the results in the second and third columns. Table 2 shows the 10 most significant differences in key concepts and the 20 most significant differences in key words, in order of greatest difference ${ }^{i}$. 
The key concepts in the upper section of Table 2 show different areas of conversation. This provides an insight into the topics that interviewees emphasised and indicates what they considered to be important to them at that particular juncture. Columns 1 and 2 show that both social and private sector entrepreneurs are significantly more likely to talk about general business concepts and wealth (money: affluence) in comparison to general spoken English. Other key concepts show different patterns of conversation. Social entrepreneurs are most different to the BNCSE on social, local and human concepts, whereas general entrepreneurs show a greater preoccupation with ability and power. A comparison of the social entrepreneur texts directly against spoken text of private sector entrepreneurs (CESB), shows no significant difference in the amount of discussion of general business concepts. However, social entrepreneurs are more likely to talk about groups and affiliations, obligation and necessity, government, helping and hindering, social actions and general work or employment concepts. They are significantly less likely to talk about selling aspects of business, personal belongings or food.

The lower section of Table 2 shows the top 20 most significant differences at the more detailed level of specific words. Again, there are few similarities in the comparison of social entrepreneurs and private sector entrepreneurs with BNCSE. Very different words were used by each group when asked to talk on the same subject. Furthermore, the following were either very low on the social entrepreneurs' list (eg did not differ significantly from the norm) or were not present at all: market $(+12.97)$, opportunity $(+29.26)$, profit $(+23.48)$, risk $(+19.07)$; trading; income, sustainability, performance. This may be considered surprising, given the context and discussion topic.

One of the most striking differences was in the use of the pronouns $\mathrm{i}$ and we. Column 1 highlights that social entrepreneurs are significantly more likely to use the word we in comparison to general spoken English and Column 3 shows that they are also significantly more likely to use we in comparison to private sector entrepreneurs. 
Indeed, for the social entrepreneurs, the word we is the second highest frequency word overall. Furthermore, the first person singular $\mathrm{i}$ is used significantly less frequently by social entrepreneurs relative to private sector entrepreneurs. Social entrepreneurs are also less likely to use the pronouns he and you. These differences in the use of pronouns could reflect a greater emphasis on collective agency by social entrepreneurs.

As expected, social entrepreneurs are significantly more likely to use the words community and social in comparison to general spoken English and private sector entrepreneurs. In addition, social entrepreneurs are more likely to use local place names which could also indicate a greater affinity with the local community.

In comparing social entrepreneurs to private sector entrepreneurs, column 3 in Table 2 shows that social entrepreneurs are more likely to use the words funding, project, volunteers and committee, which are words more associated with community development than business enterprise. Interestingly though, social entrepreneurs are more likely to use the words enterprise and entrepreneur than private sector entrepreneurs.

This highlights that it is not sufficient to analyse the frequency of word use but it is necessary to also consider the words in context. Analysis up to this point presents only a snapshot of the dominant concepts and lexical items manifested on the surface of the texts as a whole. The differences in word use identified here and the review of literature presented earlier provide the basis for identifying themes to be explored in greater depth in the next stage of analysis.

\subsection{Meanings in Discourse}

Having identified potential areas of difference between social entrepreneurs and the other two groups, the analysis explores the language of social entrepreneurs in context 
and in greater depth. Critical discourse analysis was undertaken on five transcripts of the interviews with social entrepreneurs, referred to here as Samples 1 through 5 . The results are presented here in terms of five themes arising out of the earlier discussion: identity of social entrepreneurs; portrayal of activity as entrepreneurial; resonance of entrepreneurship discourses; affinity with the entrepreneurial narrative or myth, and reproduction of ideologies and social practices.

\subsubsection{I dentity}

Identities appeared to be constructed from an inbetween-ness within the local environment, rather than the brokerage role suggested by etymological explanations of entrepreneurship in terms of entre prendre. As the wmatrix results indicated, the interviewees seemed to take their identities and their activities' meanings from the position between two main social presences: their community and the regeneration professionals, rather than through their own character, status or activity:

"so I suppose the professionals, if you like, involved, had to bring the community on board a lot quicker than they probably would have done to get to fit in with all this funding. We..."

Community and the professionals were present as an imagined audience (Van Dijk 1997) and people generally were forefront in the speakers' awareness. Being part of a collective identity was important and locality was a prominent factor in the construction of identities:

“...and if we don't do something about it now we'll become one of these totally deprived areas." (Sample 1)

Here, Sample 1 frames a collective identity in terms of the 'area'. Throughout the samples, the use of the collective pronoun 'we' was prevalent. There is a notable flux in the speakers' position vis a vis the community, where the first person agency comes in 
and out of focus against the backdrop of community and collective agency. The following sample illustrates this, as well as providing another example of identity framed in terms of locality:

"and what we would really like to do is have control of our own..so we're developing a plan for the village...So it's about doing things that help the people." (Sample 4)

Agency for making things happen was found to be prominent to the interviewees, as in earlier conceptualisations of the entrepreneur (Nicholson and Anderson 2005). Agency was clearly seen in following three elements: transitivity, voice and subject position.

Verbs were predominantly transitive in that the object and agency is clear, as in "me empowering them" (Sample 4). The dominant voice was active, active being the unmarked choice (Fairclough, 1997:182). Occasional shifts into the passive seem to coincide with certain events where external agency was key or with references to their own career or story and where confidence seemed lower:

“To be honest wi'ya, if somebody told me five year ago I'd be here doing what I'm doing today, I'd have laughed at them. And I was asked because of my experience..." (Sample 2)

This sense of agency was reinforced by subject position. All the speakers established a stance as local knowledge holder and champion for their community. The speakers in Samples 2 and 4 also assume the position of an instructor/teacher at certain points, with the reader as learner of community enterprise. Both speakers use rhetorical devices of teaching, with rhetorical questions and answers negating presupposed answers.

“What makes you want to do it? Because it's not being done.... What motivates you? Well it isn't money."

Samples 2 and 3 use the rhetorical mode of an orator: "and that's what I'm saying. Comes from the gut right, comes from the heart..." as does Sample 1. 
Interestingly, despite the strong sense of agency, responsibility and causality were sometimes transferred to outsiders, often those seen as being the 'professionals':

“there were all these people, we don't understand what they're saying half the time" and "then someone came in from the North East to do this training and we went through all this training..." (Sample 5)

In this, the professionals were framed mainly negatively as preventing agency at the local level:

"so instead of [council] or the county council telling us what to do, it's about getting what we want." (Sample 1)

The analysis built up a complex picture of the social entrepreneurs as agents in a collective community process. Identity seems to be legitimised more through a stewardship function than any sense of entrepreneurial personality and that legitimacy seems to be drawn from a local-social morality which would be worthy of further exploration.

\subsubsection{Portrayal of activity}

Activity was given a great deal of prominence in the interviews, with an emphasis on processes and action. Process types used were mainly action and relational in nature, with a notable absence of emotional or cognitive process types. This is interesting given the topic and interview situation which might be expected to draw out reflexivity. Mental processes were used mostly in Sample 5, where they were subjective, I think, I suppose but often tempered by statements such as “...but other people wouldn't say that...”

Mostly, speakers avoided nominalisations, the turning of a verb into a noun. Nominalisation has the effect of backgrounding the actual process and creating distance between the speaker and activity (Fairclough 1995). Where they were used, (e.g. 
employment, funding, decline, submission, partnership working, renewal, training, achievement) they appeared to be echoes of rhetoric and agency speak.

Activity can also be looked at through local theme, which in the samples was often carried through a referent rather than made explicit. This is most commonly a conjunction, adjunct or article, which gives the reader the sense that the activity is undefined. The nature of the interviewees' purpose takes on an amorphous form. Numerous references are made to something, it or things throughout all the interviews; doing something/doing something about it, getting things done, doing things differently, putting something back are prominent:

"er it is making things happen and in a word that's probably it. Er, standing joke around here er is me saying 'make it happen' but that's me empowering them and trying to get other people to do things not talk about, not plan." (Sample 4)

In this, the speakers avoided defining their activity; this was more often achieved by talking about what it was not or how it differed from the mainstream. This might suggest that the process or presence itself was important, the what, how or outcome being less significant. This resonates with Pearce's view (2003:68) that many people involved in social enterprise are "getting on with it" or "getting the job done". Where the outcome or impact of activity was evident, it was expressed in relation to place and people: "it's seeing people that come on board that have learning difficulties and watch them turn theirselves around" (Sample 2) and "it's about doing things that helps the people." (Sample 4)

The modality of the texts rooted activity firmly in the here and now. Two main tenses were used in all the samples: simple present/past, which represent a categorical modality (Fairclough 1997:158) of is and was; and the past/present continuous, for immediacy and proximity. There was a discernible absence of any future tense, though the conditional was used occasionally. This gave the texts a less forward-looking 
visionary perspective than might be expected of entrepreneurs and reinforces the temporal importance of action (Shaw et al. 2001).

Modal auxiliaries were virtually never used (and this was also indicated by the wmatrix results), with the exception of equivalents of must: has to, have to, needs to. This gave an overall sense that the social entrepreneurs were driven by obligation rather than opportunity. This appeared to come from a sense of duty in the absence of other agents. One paragraph in Sample 3 demonstrates this:

"we have to prove we're good enough ...we really have to be sustainable now .... it does need business standing .... so it has to grow with the people of [place] and the benefit of [place]. It has to grow and it has to be good." (Sample 3)

In Sample 4, opportunity was rationalised as need:

“What makes you want to do it? Because it's not being done. There's a market gap.... So identify the need, respond to the need." (Sample 4)

Activity thus seemed to play an important role in creating the sense of agency discussed above. The vague nature of the activity and its connectedness to need rather than opportunity affirmed an activity that was at odds with conventional constructions of entrepreneurship. The attention to action, duty and need appears more closely aligned with the social morality discussed above. There was little emphasis on outcomes and more discussion about the process of doing something. The lack of any emphasis on the future or opportunities is of interest.

\subsubsection{Resonance of entrepreneurship culture and discourses}

Intertextuality refers to the snatches and influences of other texts that can be manifest or interwoven into the texts (Fairclough 1995). Echoes of the prevailing rhetoric in the political environment were evident throughout, often in articulating local problems and prescribed solutions, to convey technical or political information. As discussed earlier, 
there is a lot of discussion in political arenas about social enterprises becoming more business-like. As the interviewees were all nominated by local agencies it is safe to assume that they would have been exposed to this language. The intertextuality of this discourse was reinforced by the interviewees in the level of presupposition, the assumed prior knowledge of the reader. Presupposition was widespread regarding the local context, the bureaucratic environment and current social/community enterprise agendas. In this sample the "does" acts as a cue:

"So it does need business standing behind it and that's why I took my diploma. We do see ourselves as a business." (Sample 3)

Business terms were brought in, but woven in to an explanation of community which appeared to be dominant.

“I'm a manager of a community group...People who can't get a job, we're actually helping them. Which general businesses don't do, for some reason."

“It isn't necessarily doing things according to a business plan, it isn't necessarily doing things that are written down, alternative targets and objectives..."

Business forms appeared to be interchangeable with forms of community organisations. Interesting instances of rewording appeared in Sample 2, with frequent redefinitions of the company as a 'scheme', 'project' or 'group'. Business was directly associated with negative connotations such as 'dirty', 'ruthlessness', 'ogres', 'exploiting the black economy', 'wealth and empire building' and 'treating people as just second class'. Money, too, seemed to be a pre-occupation, as the wmatrix results indicated, but closer analysis highlighted that it was mainly funding that was emphasised. There were some mentions of profit, although in the main example it was justified as "profit is not a dirty word". 
In Sample 5, the word stuff was used frequently. This could be analysed partly as hedging but is more likely to be representational of terminology with which the speaker was uncomfortable, in this case business models:

"well all the constitution stuff, the legal stuff about being a company erm budget control. So there was all that kind of stuff going on."

Hedging was common around propositions that were technical or politically or culturally sensitive, particularly money, rhetorical soundbites and business speak. Some hedging was also evident around the construction of social problems. "We're helping a lot of people with learning difficulties and things like that." or "She had problems at home and things like that." Hedging suggests either low association with the proposition or that the speakers felt that they were outside their legitimacy. This seems the more likely explanation in Sample 5:

“and then, the residents association stuff wasn't really, I didn't, it wasn't really for me I don't think you know it was the sort of they'd been going there for the tea and the, not that I'm don't get me wrong I'm not sort of..."

The analysis would indicate that the discourse of entrepreneurship was neither manifest in the spoken text of the interviewees, nor intertextually influential. Critically, there appeared to be greater intertextual influence from a number of external discourses, including: exclusion, employment, community, regeneration, business and biology.

\subsubsection{Affinity with the entrepreneurial myth and narrative}

There were surprisingly few references to entrepreneurs/ship throughout the interview texts. Where they did occur, references were most often to mainstream business or the businessman. The interviewees responded to questions about them being social entrepreneurs by openly dismissing the concept, with statements such as: 'it's amusing!', 'it's ridiculous!', 'too posh..J'm working class'. This working class theme is 
reiterated in other UK studies e.g. Cohen and Musson (2000). Low affinity could be seen through a form of semantic engineering - articulating around the word a series of qualities that the proponent or speaker associated with the proposition (Fairclough 1992:132). The interviewees' conceptualisations of entrepreneurship were articulated only in terms of opposition to 'true entrepreneurship' and 'general business'. There appeared to be a dislocation between their perception of the myth of the entrepreneur and their work in the social context. At the same time, both community and the 'system' were depicted as emphatically non-enterprising.

Metaphoric and other figurative language mainly portrayed the role of the interviewees as protectors and champions. Dominant themes included: shepherding (getting things moving, bringing them in/round/on board, getting people through gateways and barriers, going round and round and round), battle, though often in sense of the lost battle (charging into, hard slog, banging heads against brick walls, running round in circles), expedition (climbing Everest, steep curve, inclines and declines) and nurturing (renewal, regeneration, growing, organic growth, inhibitors). Notably, the interviewees did not use language around heroes, risk or innovation.

The social entrepreneurs would appear to have low affinity to heroic conceptualisations of the entrepreneur but there might be some affinity with the entrepreneur as saviour (Nicholson and Anderson 2005).

\subsubsection{Reproduction of ideologies and social practices}

Earlier analysis of intertextuality highlighted that social entrepreneurs were echoing the prevailing rhetoric regarding becoming more business-like. In terms of social relations and structures, the texts of the social entrepreneurs were seen to be reinforcing and reproducing long standing tensions between local government and community, in 
particular the struggles over local development, empowerment and involvement (Oatley 1998). The reproduction of these relations suggests that these issues are deep seated, and re-politicises the environment and logic of social entrepreneurship.

Social identities were demarcated through the ethos of the samples. Communities (the community, community, people, the people, they, these people) were socially pathologically constructed as being in need of saving and associated with peripherality and out there-ness. For example, "Always did things on the side, such as, erm community groups" (Sample 4). As indicated in the previous section, part of the social entrepreneur's role was perceived in breaking down physical and virtual barriers and helping people through gateways and barriers. Groups were rarely defined more tightly than 'people' or 'community', except in Samples 5 and 2, where the residents group and young people with learning difficulties were specified. There was a sense that the speakers did not have the resources available to them to distinguish further within the complex metaphor that is community (Myerson and Rydin 1997). This could symbolise that the interviewees saw themselves reaching the undefined within the community, in other words those outside target groups prescribed through policy initiatives. There were hints of a transformational objective regarding people in the community (Hastings 1999) such as "me empowering them" and "we're helping them", although more often this was represented also as coming top-down from the "professionals".

As seen earlier, the professionals and local government in particular were depicted as an obstruction ("hit a brick wall with them", "it's like banging your head against a brick wall"). The social identity of the official as non-entrepreneurial and non-dynamic was reinforced throughout, as in the following series of negative polemical cues in Sample 4:

“it isn't because you're a bureaucrat, and it isn't because you're a local authority person. None of those fit. It's not a nine to five, it's not a routine, it isn't a job that you can write down on a piece of paper..." 
The speakers appeared to seek the complicit support of the interviewer in defining these social positions. There are numerous, sometimes explicit, attempts to establish affinity through tags such as "you know", and, in Sample 4, "you ought to see them." A negative tag is used in Sample 5 for the same effect, "some people are better at partnership working, aren't they, you know."

Though not oppositional at text level, the discursive practices controlling the production and consumption of the texts were oppositional, in that they appeared to defy the notion that self determination over community problems or local issues was best dealt with through entrepreneurship. The reader might also identify the irony that the proponents of social entrepreneurship as part of a strategy for local development and social inclusion are still central to the construction of the problem.

\subsection{Discussion}

The analyses present a complex picture of the interviewees as agents and stewards in collective, locally situated processes. The wmatrix analysis highlighted a preoccupation with social, local and human concepts, including groups and affiliations, obligation and necessity, and helping and hindering. The pronoun 'we' was prominent and, as expected, social entrepreneurs are significantly more likely to use words conventionally associated with the project of community development or regeneration than entrepreneurship. This was all reinforced through the discourse analysis, which marks a collective logic, in part political (around fighting the system), in part action-oriented (doing something, getting the job done) in which activity itself is the object and rooted firmly in the here and now, rather than aspirational of future outcomes. 
However, the wmatrix results also showed an interesting overuse of the words enterprise and entrepreneur and the key concept business (both generally and specifically in terms of selling). The in-depth analysis allowed us to look at this more closely. The occurrence of enterprise, entrepreneurship and entrepreneur concepts is mainly in reference to 'business', as opposed to social entrepreneurship, and drawn on as a negative comparator or as a frame against which to define their own, different status or activity. Business people are presented as 'ruthless' or 'ogres'; trading as contraband; money as a compromise to their values; and entrepreneurs as belonging to a different value system and class. Perhaps notable by their absence are building blocks of entrepreneurship that might be associated with a conventional reading of the enterprise discourse, including innovation, risk, proactiveness, market and opportunities, profit and personal drive.

The texts clearly locate the entrepreneur, or entrepreneurship, within a conventional, popular reading of the concept or from a neoconservative perspective. At the same time, however, the purpose of this reference is most often expressly to demonstrate low affinity with the concept. For instance, the social entrepreneurs reproduce but appear to have very low affinity with heroic conceptualisations of the entrepreneur, although there might be some affinity with the entrepreneur as saviour (Nicholson and Anderson 2005). The analysis would indicate that the discourse of entrepreneurship was manifest in the spoken text of the interviewees, but only intertextually influential in defining what does not apply to them.

In the process, the discourse becomes altered, combined with other discourses, particularly those of management, leadership and, not least, community development or activisim. Resonances of the enterprise discourse are not only appropriated but, we argue, assimilated under these other discourses. For example, opportunity recognition and starting new activities was evident but redefined in relation to social need rather than opportunity. Engagement with these moments of need is also often presented as 
reactive or happenstance rather than proactive. In another example, failure of the enterprise is conceptualised in terms of protecting the community, of letting them down. Success, equally, is articulated as recognition and resilience, rather than performance.

Although the transcripts are not particularly oppositional at text level, the discursive practices controlling the production of the texts do appear oppositional. They defy the notion that self-determination over community problems or local issues is best dealt with through business or entrepreneurship, as the rhetoric suggests. A brief review of core policy and strategy texts from national, regional and local agencies ${ }^{\mathrm{ii}}$ identified the following concepts: doing lots with very little, financial independence through sustainability, contributing to the mainstream economy, bringing business discipline to social ventures, innovating for change, helping people take charge of their lives and futures. The only category that appears to be evident within this study is around helping people take charge of their lives. A chasm is therefore apparent between these dominant concepts in the rhetoric around social enterprise/entrepreneurship and the onthe-ground constructions. It is no surprise that the language of agency documents differs from the text of research interviews. It does serve as a reminder, however, that entrepreneurship is a complex social construction whose central concepts are contested. The reader might also identify the irony that the proponents of social entrepreneurship as part of a strategy for local development and social inclusion (local authorities particularly but also development agencies, government departments etc) are central to the construction of the problem.

Most strikingly, the interviewees seem to draw their legitimacy as activists, guardians or indeed entrepreneurs from a sense of social morality, rather than from the entrepreneurship discourse directly, as might be expected from 'mainstream' entrepreneurs. As evidenced in related studies, such as Cohen and Musson (2000), what may be emerging from these findings is a 'modified' social construction of entrepreneurship that strongly resists the hegemony of the enterprise discourse by 
drawing elements from other discourses to make sense of micro realities. At the same time it allows the enterprise discourse to work in an apparently hegemonic way even though it is contested. The values and meanings attached to the entrepreneurship discourse as it is appropriated may be quite different or similar to those in 'mainstream' enterprise but this would need further exploration, if indeed social constructions are comparable at this level.

The approach used in this study inevitably experiences challenges to do with methodology and conceptual clarity. Not only are we dealing with the moving semantic target of entrepreneurship across two disciplines, but in taking the view that meaning is produced in context, that contextuality - individuals in a particular sub-region of the UK at a given time - must be respected. It is difficult to know what meanings and values are drawn on by the interviewees in making sense of their realities outside the scope of these particular interviews. Moreover, it is impossible to generalise about social entrepreneurs on the basis of a small sample. Views on the interviewees' apparently weak identification with the entrepreneurship discourse may alter if further, particularly longitudinal, data could be collected.

Low affinity could be explained by cultural as well as conceptual reasons that could apply equally to 'entrepreneurs' from small business. For example, discussing entrepreneurship could be outside the linguistic resources of the interviewees in that particular time and place; or the myth of the entrepreneur may be perceived as inaccessible or as the preserve of big players, leading interviewees to talk about more comfortable themes. Interpretations of the findings could also be wide ranging depending on the readers' perspectives. This is inevitable if the relationship between text producer, interviewer and indeed reader is dialectical and we are all involved in the production of meaning at the time. Our approach to data collection and analysis acknowledges these predicaments and attempts to circumnavigate them by combining 
the grounded, interpretive perspective of phenomenological enquiry with the socially critical framework of Critical Discourse Analysis.

\section{Conclusion}

This paper has shown that, in the case of these 'social entrepreneurs' operating in the UK, the frames of reference used to construct and articulate their realities are multiple and resonate closely with other discourses that compete with and ultimately reappropriate meaning to elements of the entrepreneurship discourse (Cohen and Musson 2005, Fletcher 2006). The ideological and cultural meanings central to their social construction seem to centre around three main tenets: their position within the ideological struggle between local government and community; need-driven action, anchored firmly in the present and immediate past; and collective action for local change.

The activities labelled under social entrepreneurship thus re-appear as political (Cho 2006) and dependent on their 'in between' position to exist, rather than as economic entities in their own right. This position may be between community and the 'system' from a political perspective; between localities and wider institutional structures; between need (as a result of state/private sector failure) and opportunity (from the same failure); or between ideologies and social values and the attainment of social change towards those values.

A collective logic dominates and the reader is left with the sense that these particular 'social entrepreneurs' draw their legitimacy from other (social and moral) sources than the entrepreneurship discourse. These social entrepreneurs are seen operating literally in a different world of meaning (Paton 2003), driven by discourses of social need and moral duty. The entrepreneurial turn, if it promotes a monological perspective (Cho 2006) does present a challenge to policy that applies it to social gaps and social change 
(Perrini and Vurro 2006) and to research from a management or entrepreneurship discipline that fails to take account of the political sociology of the movement.

We are not suggesting that activity in the social or community context should not be classed as entrepreneurial or indeed that the reality of the modern environment in which social enterprises and entrepreneurs operate does not necessitate the adoption of certain discourses such as sustainability and business management. We do suggest though that the conceptual assumptions in the dominant entrepreneurship discourse, critiqued by many entrepreneurship researchers, may constitute an even wider chasm when applied to people and processes in the domain labelled social entrepreneurship. It appears that political engagement and collective action still have currency to those operating on the ground and that democratic structures may be equally as prominent as the focus on social activity. It is also a reminder that discursive shifts, driven by policy makers, funders, the sector and academics alike, do not necessarily infiltrate ideology at the level where the action is located. Therefore, while the questions of how to back the winning product, process or person may become accepted, to many they may propagate a focus that is difficult to contest and could influence the use of resources.

Further research should continue to explore discourse analysis approaches. The microscopic technical focus on language, and the production of meaning, seeks a degree of objectivity by de-coupling, momentarily, the analyst from their subjective reading of the texts but is set within an overtly subjectivist framework, in which the social and political stance is made clear (Fairclough 1995). It avoids some of the unavoidable subjectivity of interpretation involved in analysis even of phenomenological enquiry in entrepreneurship, as noted by Thompson et al (1989). Most importantly perhaps, it captures the voices of those most often assumed to be the object of, rather than a subject in the production of, the discourse of which they form the centre. Future research should consider a longer term study which would capture the naturalisation (and possibly assimilation of) the entrepreneurship paradigm. 
Notes

i. The plus sign (+) before the LL figure (log-likelihood) shows relative overuse, the minus sign (-) shows relative underuse. Above or below 6.63 is considered significantly different from the norm. For the purposes of the report, insignificant words such as "yeah", "er", "y'know" have been removed (this would be significant for other forms of linguistic or discourse analysis such as conversation analysis).

ii. From a brief review of the DTI's Social Enterprise: A Strategy for Success (2002), School for Social Entrepreneurs and Community Action Network websites, North West Development Agency Social Enterprise Survey (2003) and the West Cumbria Social Enterprise Hub proposal (West Lakes Renaissance, 2005).

\section{References}

Ahl, H. 2004 The scientific reproduction of women's entrepreneurship: a discourse analysis of research texts on women's entrepreneurship, (Copenhagen Business School Press).

Alvord, S.H., Brown, L.D., Letts, C.W., 2004 Social entrepreneurship and societal transformation, Journal of Applied Behavioural Science, 40(3): 260-282.

Amin, A., Cameron, A. and Hudson, R. 2002 Placing the Social Economy (London: Routledge).

Anderson, A.R. 2005 Enacted metaphor: the theatricality of the entrepreneurial process, International Small Business J ournal, 23(6): 585-603.

Anderson, A.R., Jack, S.L. The articulation of social capital in entrepreneurial networks: a glue or a lubricant? Entrepreneurship and Regional Development, 14(3): 193-210.

Atkinson, R. 1999 Discourses of partnership and empowerment in contemporary British urban regeneration, Urban Studies 36(1):59-72.

Austin, J.E. 2006 Three avenues for social entrepreneurship research, in J. Mair, J. Robinson and K. Hockerts (eds), Social Entrepreneurship (Basingstoke: Palgrave Macmillan).

Blackburn, R. and Ram, M. 2006 Fix or fixation? The contributions and limitations of entrepreneurship and small firms to combating social exclusion, Entrepreneurship and Regional Development, 18(1): 73-89.

Busenitz, L.W., West, G.P., Shepherd, D. Nelson, T., Chandler, G.N. and Zacharakis, A. 2003 Entrepreneurship research in emergence: past trends and future directions, Journal of Management 29:285-308.

Cabinet Office 2006 Social Enterprise Action Plan: Scaling New Heights. Office of the Third Sector, Cabinet Office (London: HM Government).

Cave, F., Eccles, S., Rundle, M. 2001 Attitudes towards entrepreneurial failure: A learning experience or an indelible stigma? Proceedings of the 2001 Babson CollegeKaufman Foundation Entrepreneurship Research Conference, Jonnkoping, Sweden, May. 
Chell, E. and Allman, K. 2001 The development of high technology enterprise from HEIs: methodological considerations, paper presented to the $9^{\text {th }}$ Annual High-tech Small Firms Conference, Manchester Business School, 31 May-1 June.

Cho, A.H. 2006 Politics, values and social entrepreneurship: A critical appraisal, in J. Mair, J. Robinson and K. Hockerts (eds), Social Entrepreneurship (Basingstoke: Palgrave Macmillan).

Cohen, L. and Musson, G. 2000 Entrepreneurial identities: reflections from two case studies, Organization, 7(1): 31-48.

Collins, C. 1999 The dialogics of community: language and identity in a housing scheme in the West of Scotland, Urban Studies, 36(1):73-90.

Cope, J. 2005 Researching entrepreneurship through phenomenological inquiry: philosophical and methodological issues, International Small Business Journal, 23(2): 163-189.

Covin, J.G. and Slevin, D.P. 1991 A conceptual model of entrepreneurship as firm behaviour, Entrepreneurship Theory and Practice 16 (1) 7-26.

Deakins, D., Mohammed, I., Smallbone, D., Whittam, G. and Wyper, J. 2007. Ethnic minority businesses in Scotland and the role of social capital, International Small Business J ournal, 25(3):307-326.

Dees, G. 2004 Rhetoric, reality and research: Building strong intellectual foundations for the emerging field of social entrepreneurship, paper presented at the 2004 Skoll World Forum on Social Entrepreneurship, March 2004, Oxford.

Drucker, P. 1994 The Age of Social Transformation, Atlantic Monthly, 274: 53-80.

DTI 2002 Social Enterprise: a Strategy for Success, (London: Department of Trade and Industry).

Du Gay, P. 1991 Enterprise culture and the ideology of excellence, New Formations, 13:45-61.

Du Gay, P. 2004 Against 'enterprise' (but not against 'enterprise' as that would make no sense), Organization, 11(1):37-57.

Evans, M., Syrett, S. and Williams, C.C. 2004 The Informal Economy and Deprived Neighbourhoods: a systematic review (London: Office of the Deputy Prime Minister).

Fairclough, N. 1995 Critical Discourse Analysis: The Critical Study of Language, (London: Longman).

Fairclough, N. 1992 Discourse and Social Change, (Cambridge: Polity Press).

Fairclough, N. 1989 Language and Power, (London: Longman).

Fairclough, N. and Wodak, R. 1997 Critical discourse analysis, in T. van Dijk (ed) Discourse as Social Interaction, (Sage: London).

Fletcher, D.E. 2006. Entrepreneurial processes and the social construction of opportunity. Entrepreneurship and Regional Development, 18(5):421-440.

Foucault, M. 1972 The Archaeology of Knowledge, (New York: Pantheon Books). 
Foucault, M. 1982, The Subject and Power, in H. Dreyfus and P. Rabinow Michel Foucault: Beyond structuralism and hermeneutics, (Chicago: University of Chicago Press).

Gartner, W.B. 1988 "Who is an entrepreneur?" is the wrong question, American Journal of Small Business, Spring 1988, 11-32.

Grant, P., and Perren, L. 2002 Small business and entrepreneurial research: Metatheories, paradigms and prejudices, International Small Business Journal 20(2): 185-211.

Hastings, A. 2000 Discourse analysis: what does it offer housing studies? Review article, Housing, Theory and Society, 17:131-139.

Hastings, A. 1999 Analysing power relations in partnerships: Is there a role for discourse analysis? Urban Studies, 36(1):91-106.

Haugh, H. 2006 Social enterprise: beyond economic outcomes and individual returns, in J. Mair, J. Robinson and K. Hockerts (eds), Social Entrepreneurship, (Basingstoke: Palgrave Macmillan).

Haughton, G. 1998 Principles and practice of community economic development. Regional Studies, 32(9):872-877.

Haywood, G. and Nicholls, J. 2004. Enterprise dynamics in the $20 \%$ most deprived wards in England. Betamodal Ltd.

Hjorth, D. and Johannisson, B. 2003 Conceptualising the opening phase of regional development as the enactment of a 'collective identity', Concepts \& Transformation, 8(1):6992.

Hjorth, D. and Steyaert C. 2004 Narrative and Discursive Approaches in Entrepreneurship, (Cheltenham: Edward Elgar).

Hodson, R. and Kaufman, R.L. 1982 Economic dualism: a critical review, Ame rican Sociological Review, 47(6): 727-739.

Holmquist, C. 2003. Is the medium really the message? Moving perspective from the entrepreneurial actor to the entrepreneurial action, in C. Steyaert and D. Hjorth (eds), New Movements in Entrepreneurship: 73-85 (Cheltenham: Edward Elgar).

Howorth, C., Tempest, S. and Coupland. C. 2005 Rethinking entrepreneurship methodology and definitions of the entrepreneur, Journal of Small Business and Enterprise Development, 12(1), 24-40.

Jacobs, K. 2004 Waterfront redevelopment: A critical discourse analysis of the policymaking process within the Chatham Maritime Project, Urban Studies 41(4): 817-832.

Jennings, P.L., Perren, L., Carter, S. 2005 Guest editors' introduction: alternative perspectives on entrepreneurship research, Entrepreneurship Theory and Practice, 29(2): 145-152.

Johannisson. B. 2002 Energising entrepreneurship: Ideological tensions in the mediumsized family business, in D. E. Fletcher (ed) Understanding the Small Family Business (London: Routledge). 
Johannisson, B., Ramirez-Pasillas, M. and Karlsson, G. 2002 The institutional embededness of local inter-firm networks: a leverage for business creation, Entrepreneurship and Regional Development, 14(4): 297-315.

Jones, C. and Spicer, A. 2005 The sublime object of entrepreneurship, Organization, 12(2): 223-246.

Kilkenny, M., Nalbarte, L. and Besser, T. 1999 Reciprocated community support and small town - small business success, Entrepreneurship and Regional Development, 11(3): 231-246.

Kirzner, I.M. 1973 Competition and Entrepreneurship, (Chicago: University of Chicago Press).

Krashinsky, M. 1998 Does Auspice Matter? The Case of Day Care for Children in Canada. (New Haven and London: Yale University Press).

Laukkanen, M. 2000 Exploring alternative approaches in high-level entrepreneurship education: creating micro-mechanisms for endogenous regional growth, Entrepreneurship and Regional Development, 12(1): 25-47.

Lindh de Montoya, M. 2004 Driven entrepreneurs: a case study of taxi drivers in Caracas. In D. Hjorth, C Steyeart (eds) Narrative and Discursive Approaches in Entrepreneurship, Cheltenham: Edward Elgar.

Lloyd, P. and Mason, C. 1984 Spatial variations in new firm formation in the United Kingdom: comparative evidence from Merseyside, Greater Manchester and South Hampshire, Regional Studies, 18(3): 207-220.

Mair, J. 2006 Exploring the Intentions and Opportunities Behind Social Entrepreneurship. In J. Mair, J. Robinson and K. Hockerts (eds), Social Entrepreneurship, (Basingstoke: Palgrave Macmillan).

Mair, J. and Marti, I. 2006 Social entrepreneurship research: A source of explanation, prediction and delight, Journal of World Business, 41(4):36-44.

McEnery, A. M. and Wilson, A. 2001 Corpus Linguistics (Edinburgh: Edinburgh University Press).

Michael, A. 2006 Securing social enterprise's place in the economy, Social Enterprise Coalition Conference, Manchester, 25 January 2006. SBS press release. www.sbs.gov.uk/sbsgov/action/news.

Myerson, G., Y. Rydin 1996 The Language of Environment: A new rhetoric, (London: UCL Press).

Nicholson, L. and Anderson A.R. 2005 News and nuances of the entrepreneurial myth and metaphor: Linguistic games in entrepreneurial sense-making and sense-giving, Entrepreneurship Theory and Practice 29 (2) 153-172.

Nolan, A. 2003 Entrepreneurship and local economic development: programme and policy recommendations, (OECD: Paris).

NWDA 2003 Social Enterprise Survey, (Warrington: North West Development Agency).

Oatley, N. 1998 Cities, Economic Competition and Urban Policy (London: Paul Chapman). 
Ogbor, J.O. 2000 Mythicizing and reification in entrepreneurial discourse: ideologycritique of entrepreneurial studies, J ournal of Management Studies, 37(5): 605-635.

Parker, I., 1999 Critical Textwork: An introduction to varieties of discourse and analysis, (Buckinghamshire: Open University Press).

Parkinson, C. 2005 Meanings behind the language of social entrepreneurship. Lancaster University Management School Discussion paper 2005/072.

Paton, R. 2003 Managing and Measuring Social Enterprises, (London: Sage).

Pearce, J. 2003 Social Enterprise in Anytown, (London: Calouste Gulbenkian Foundation).

Perren, L. 2002 Comparing entrepreneurship and leadership, working paper CEML, London.

Perrini, F. and Vurro, C. 2006 Social entrepreneurship: innovation and social change across theory and practice, in J. Mair, J. Robinson and K. Hockerts (eds), Social Entrepreneurship, (Basingstoke: Palgrave Macmillan).

Pomerantz, M. 2003 The business of social entrepreneurship in a "down economy", in Business, 25(3): 25-30.

Portes, A. 1994 The informal economy, in N. J. Smelser and R. Swedberg (eds), The Handbook of Economic Sociology, pp. 426-449. (New York: Russell Sage Foundation).

Ram, M. and Smallbone, D. 2003. Policies to support ethnic minority enterprise: the English experience, Entrepreneurship and Regional Development, 15(2): 151-166.

Rayson, P. 2003 WMatrix: A statistical method and software tool for linguistic analysis through corpus comparison. Ph.D. thesis, Lancaster University.

Robinson, J. 2006. Navigating social and institutional barriers to markets: How social entrepreneurs identify and evaluate opportunities, in J. Mair, J. Robinson and $\mathrm{K}$. Hockerts (eds), Social Entrepreneurship (Basingstoke: Palgrave Macmillan).

Shane, S. 2003 A General Theory of Entrepreneurship: The Individual Opportunity Nexus (Edward Elgar: Cheltenham).

Shane, S. and Venkataranam, S. 2000 The promise of entrepreneurship as a field of research, Academy of Management Review, 25(1):217-226.

Shaw, E., Shaw, J. and Wilson M. 2001 Unsung Entrepreneurs: Entrepreneurship for Social Gain, (Durham: University of Durham Business School).

Southern, A. 2005. Enterprise and Regeneration. Seminar paper presented to First Lancaster Social Entrepreneurship Research Seminar, Lancaster University, September 2006.

Spear, R. 2006 Social entrepreneurship: A different model? International Journal of Social Economics, 33(5/6) 399-410.

Stenson, K., and Watt P. 1999 Governmentality and the 'Social', Urban Studies, 36(1): 189-201. 
Steyaert, C. 2004 The prosaics of entrepreneurship, in D. Hjorth, and C. Steyeart (eds.) Narrative and Discursive Approaches in Entrepreneurship, (Cheltenham: Edward Elgar).

Steyaert, C., and Katz, J. 2004 Reclaiming the space of entrepreneurship in society: geographical, discursive and social dimensions, Entrepreneurship and Regional Development 16(3): 179-196.

Thompson, C., Locander, W. and Pollio H. 1989 Putting consumer experience back into consumer research: The philosophy and method of existential phenomenology, Journal of Consumer Research, 16:33-146.

Tolbert, C. M., Lyson, T.A. and Irwin, M. D. 1998 Local capitalism, civic engagement, and socio-economic well-being, Social Forces, 77(2): 401-427.

Van Dijk, T. 1997 The Study of Discourse in T. Van Dijk (ed) Discourse as Structure and Process, (London: Sage).

Wallace, S. 1999 Social entrepreneurship: The role of social purpose enterprises in facilitating community economic development, Journal of Developmental Entrepreneurship 4(2): 153-175.

Weerawardena, J. and Sullivan Mort, G. 2005 Investigating social entrepreneurship: A multidimensional model, J ournal of World Business 41 (2006) 21-35.

Weiss, G. and Wodak, R. 2003 Critical Discourse Analysis: Theory and Interdisciplinarity, (Basingstoke: Palgrave MacMillan).

Williams, C.C. 2005 Tackling undeclared work in advanced economies: towards an evidence based public policy approach, Policy Studies, 25(4):243-258.

Zafirovski, M. 1999 Probing into the social layers of entrepreneurship: outlines of the sociology of enterprise. Entrepreneurship and Regional Development, 11(4): 351-371. 
Table 1: Participants

\begin{tabular}{|l|l|l|}
\hline & Gender & Enterprise sector \\
\hline Alison & Female & Housing \\
\hline Amanda & Female & Community development \\
\hline Angela & Female & Community centre and cafe \\
\hline Bill & Male & Rural initiative \\
\hline Carole & Female & Community services \\
\hline Cath & Female & Community services \\
\hline Christine & Female & Community centre \\
\hline Dave & Male & Industrial tourism and education \\
\hline Diane & Female & Children's services \\
\hline Gerald & Male & Joinery workshops and community services \\
\hline Jeanette & Female & Health services \\
\hline Joanne & Female & Business and community services \\
\hline Julie & Female & Employment services \\
\hline Kerry & Female & Hostel, community centre and training \\
\hline Maria & Female & Employment services and workshops \\
\hline Mary & Female & Training and employment services \\
\hline Peter & Male & Arts and crafts recycling \\
\hline Robert & Male & Groundwork and construction \\
\hline Russ & Male & Childcare and family support \\
\hline Stuart & Male & Recycling \\
\hline Tess & Female & Credit union \\
\hline
\end{tabular}


Table 2 Most significant differences in Key Concepts (top 10) and Key Words (top 20)

\begin{tabular}{|c|c|c|c|c|c|}
\hline & $\begin{array}{l}\text { Social Entrepreneurs } \\
\text { compared to British National } \\
\text { Corpus }\end{array}$ & $L L$ & $\begin{array}{l}\text { General } \\
\text { compared to British National } \\
\text { Corpus }\end{array}$ & $L L$ & $\begin{array}{l}\text { Social Entrepreneurs compared } \\
\text { to General Entrepreneurs (CESB) }\end{array}$ \\
\hline \multicolumn{6}{|c|}{ KEY CONCEPTS } \\
\hline 1 & Business: generally & +792.55 & Business: generally & +258.54 & Groups and affiliation \\
\hline 2 & $\begin{array}{l}\text { Work and Employment: } \\
\text { generally }\end{array}$ & +673.83 & Ability:- Success and failure & +252.81 & Food \\
\hline 3 & Groups and Affiliations & +389.37 & Money: Affluence & +175.19 & Obligation and necessity \\
\hline 4 & People & +312.70 & Business: Selling & +40.5 & Government etc. \\
\hline 5 & Personal Names & -271.44 & Personal names & -33.20 & Helping/hindering \\
\hline 6 & Money: Affluence & +259.76 & Power, organizing & +32.36 & Social actions, states, processes \\
\hline 7 & Helping and Hindering & +245.62 & Ability:- Ability, intelligence & +31.90 & Work and employment: Generally \\
\hline 8 & $\begin{array}{l}\text { Social actions, states and } \\
\text { processes }\end{array}$ & +219.97 & Geographical names & +31.89 & Business: Selling \\
\hline 9 & Time: Beginning and Ending & +202.27 & $\begin{array}{l}\text { Information technology and } \\
\text { computing }\end{array}$ & +28.19 & Clothes and personal belongings \\
\hline 10 & Affect: Modify/change & +132.38 & Money generally & +26.16 & Money: Affluence \\
\hline \multicolumn{6}{|c|}{ KEY WORDS } \\
\hline 1 & community & +814.47 & uk & +252.14 & community \\
\hline 2 & we & +577.24 & us & +220.62 & social \\
\hline 3 & social & +552.70 & failure & +212.13 & we \\
\hline 4 & funding & +419.23 & ceo & +147.08 & funding \\
\hline 5 & people & +348.32 & investors & +139.74 & project \\
\hline 6 & because & +343.44 & founder & +128.05 & (District) $\mathrm{A}$ \\
\hline 7 & project & +313.73 & entrepreneur & +114.61 & centre \\
\hline 8 & entrepreneur & +282.27 & business & +110.73 & enterprise \\
\hline 9 & business & +276.73 & company & +81.18 & entrepreneur \\
\hline 10 & (District) A & +216.98 & banking & +78.55 & restaurant \\
\hline 11 & So & +213.16 & venture & +44.17 & you \\
\hline 12 & Centre & +194.70 & backed & +38.72 & (Town) WH \\
\hline 13 & Job & +189.19 & investment & +37.96 & enterprises \\
\hline 14 & organisation & +164.48 & hurt & +37.47 & volunteers \\
\hline 15 & enterprise & +150.60 & equity & +37.03 & $\mathrm{I}$ \\
\hline 16 & involved & +140.91 & dollars & +35.03 & (Region) WC \\
\hline 17 & working & +127.86 & entity & +34.41 & he \\
\hline 18 & (Town) WH & +123.15 & technology & +33.61 & committee \\
\hline 19 & money & +121.14 & market & +32.42 & local \\
\hline 20 & started & +116.91 & $\mathrm{cV}$ & +31.52 & sustainable \\
\hline
\end{tabular}

